Article Type: Research Paper

\title{
The Role of Foreign Tourists in Economic Growth: Evidence from Indonesia
}

\author{
Muhammad Azizurrohman*1, Romi Bhakti Hartarto², Yih-Ming Lin³ ${ }^{3}$ and \\ Faiza Husnayeni Nahar ${ }^{2}$
}

\section{apeN}

\section{AFFILIATION:}

1 Department of Tourism, Sekolah Tinggi Pariwisata Mataram, West Nusa Tenggara, Indonesia

2 Department of Economics, Faculty of Economics and Business, Universitas Muhammadiyah Yogyakarta, Special Region of Yogyakarta, Indonesia

\section{${ }^{3}$ Department of Applied Economics, National Chiayi University, Taiwan (R.O.C.)}

\section{*CORRESPONDENCE:}

m.azizur96@gmail.com

\section{THIS ARTICLE IS AVALILABLE IN:}

http://journal.umy.ac.id/index.php/esp

DOI: 10.18196/jesp.v22i2.11591

\section{CITATION:}

Azizurrohman, M., Hartarto, R.B., Lin, Y-M., Nahar, F.H. (2021). The Role of Foreign Tourists in Economic Growth: Evidence from Indonesia. Jurnal Ekonomi \& Studi Pembangunan, 22(2), 313-322.

\section{ARTICLE HISTORY}

Received:

25 Apr 2021

Revised:

15 Aug 2021

27 Sep 2021

Accepted:

01 Oct 2021

\begin{abstract}
Foreign tourism is indicated as one of the important instruments to encourage economic growth in several countries, including Indonesia. However, some studies only focus on the influence of tourist arrivals. Thus, the main objective of this study is to take a deeper look at the contribution of foreign tourism indicators to economic growth in Indonesia. Using panel data analysis from 33 countries between 2006 and 2016, this study applies three models: Pooled Least Square (PLS), Fixed Effect Model (FEM), and Random Effect Model (FEM). Based on the fixed-effect model, this study reveals that foreign tourist arrivals have a significant and positive effect on economic growth. However, other tourism indicators such as length of stay and expenditure of foreign tourists appear to have no contribution to economic growth. From these findings, it can be implied that the Indonesian government should not only attract more tourists to come but also design strategies to encourage tourists to spend more money and stay longer. This study also finds that depreciation of Indonesian currency and visa-free policies have a significant contribution to higher economic growth.
\end{abstract}

Keywords: Tourist Arrival; Economic Growth; Visa-Free; Exchange Rate

JEL Classification: L83; O11; Z32; Z38

\section{Introduction}

It has been more than decades that tourism has been considered as an important element to boost the economic growth of the countries, particularly in the developing countries, including Indonesia (Savaş et al., 2010). The tourism industry becomes increasingly significant for the Indonesian economy nowadays. Specifically, it has generated US\$ 14.11 billion in foreign exchange until 2018 (Statistics Indonesia, 2020). It comes from the flights, hotels, restaurants, and products from Micro, Small, and Medium Enterprises that are all the sources of foreign exchange revenues for tourism (MSMEs) (Sulasmiyati, 2019). This industry also employs a large number of people, supporting the local economies. The Indonesian government predicted that foreign tourists would contribute to 20 million visits per year, out of a total foreign exchange of US\$ 17.6 billion (Sulasmiyati, 2019). Nonetheless, the contribution of tourism to GDP has remained stable at roughly 4\% per year from 2015 to 2017 (Statistics Indonesia, 2018). 
The benefit of being host countries would be plenty enough to achieve rapid economic development as well (Pompili et al., 2019). However, the development of the tourism industry potentially has effects on the economy such as increased consumption of goods and services as well as job vacancies. If the government cannot formulate the best strategy to promote Indonesia, it may hurt tourism and economic development (Mariyono, 2017). Thus, understanding the contribution of international tourism arrivals toward economic growth is important. Many studies reveal that the main factors playing a role in tourism development include transportation capacity, an extension of paid vacation duration, and improvement in communication technology (Akin Aksu \& Aktaş, 2005). To find out the relationship between tourism and economic growth, the advantages and disadvantages of tourism growth should be taken into account (Sinclair, 1998). Tourism potentially increases the supply of currency, which in turn can reduce the foreign exchange gaps and increase personal income and taxes. In addition, international tourism contributes to the national income through increased productivity, the competitiveness of local and national business units, absorption of new workers, and increased demand for goods and services (Gaspar, 2020; Sakyi \& Egyir, 2017). On the other hand, tourists can cause environmental damage such as an increasing amount of waste and pollution. As a result, this harms local communities and the sustainability of tourism in the future. In addition, tourism activities can damage the culture of local communities along with intense tourist activities (Schneider, 1993).

Due to the importance of tourism to the economy, many researchers have attempted to analyze its contribution in recent decades. It has been found in Portugal that a $1 \%$ increase in the tourism sector infrastructure led to a $0.01 \%$ increase in per capita income (Soukiazis \& Proença (2007). The analysis further was extended into the specialization of country tourism and its role in economic growth, concluding that countries with abundant natural resources gain comparative advantage in tourism and develop more rapidly than countries specializing in manufacturing (Figini \& Vici, 2010). Furthermore, Chiu and Yeh (2016) analyzed the empirical correlation between economic growth, country size, and tourism. They found that countries relying on tourism are growing faster. They also found that small countries with strong tourism industries will develop rapidly. Fayissa et al. (2008) investigated the contribution of the tourism industry to African economic growth and development. By applying panel data from 42 African countries over 10 years, they found that tourism revenue has a significant and positive contribution to the current level of national income. Over 15 years, Samimi et al. (2013) investigated the causal and longterm relationship between tourism and economic growth in developing countries. Their results show that tourism creation and economic growth have a long-term positive relationship.

In contrast to most studies of tourism, Figini et al. (2018) showed that tourism specialization is not a panacea for resolving development and growth issues. Their empirical evidence suggested that, on average, countries that depend on tourism do not develop substantially different from other countries. Moreover, Oh (2005) looked into the long-term relationship between tourism industry's development and South Korea's national output. They concluded that tourism and economic growth have no long-term relationship. Although many studies discuss tourism and economic growth as mentioned, 
they only measured foreign tourists based on the number of arrivals. This study added other aspects of tourist arrivals such as tourist spending and length of stay to the existing literature. The inclusion of these variables is expected to add to the existing literature that has never addressed this concern.

\section{Research Method}

In this study, to evaluate whether foreign tourist arrivals lead to an increase in GDP, we use quantitative analysis with secondary data to estimate the effect. Specifically, we use panel data from 33 countries of tourists' origin over 10 years, from 2006 to 2016, to examine the effect of international tourism on economic growth in Indonesia. Table 1 presents a list of countries being used in this study. Data in this study were taken from various sources. For example, the gross domestic product (GDP) and exchange rate of IDR/USD data were retrieved from the World Bank. Tourism-related data such as tourist arrivals, length of stay, and tourist expenditures were obtained from Statistics Indonesia, while a list of countries exempted from entry visa is based on the Indonesian Immigration Office.

Table 1 Origin Countries of Tourists

\begin{tabular}{lcccc}
\hline \multicolumn{1}{c}{ Brunei Darussalam } & India & China & Sweden & Norway \\
\hline Malaysia & Japan & Australia & France & Finland \\
Philippines & South Korea & New Zealand & Spain & Switzerland \\
Singapore & Pakistan & USA & Netherland & United Kingdom \\
Thailand & Bangladesh & Canada & Italy & Russia \\
Vietnam & Sri Lanka & Austria & Germany & Belgium \\
Hong Kong & Denmark & Taiwan & & \\
\hline
\end{tabular}

A generic standard model in the following form is used to analyze the impact of tourism on economic growth.

$$
\log G D P_{i t}=\beta_{0}+\log \beta_{1} I T A_{1 i t}+\log \beta_{2} I T E_{2 i t}+\log \beta_{3} L S_{3 i t}+\log \beta_{4} E_{x i n d}{ }_{4 i t}+\beta_{5} F V_{5 i t}+\varepsilon_{i t}
$$

Where:

$\operatorname{LogGDP} P_{i t} \quad=$ Economic Growth (real GDP)

$\log \beta_{1} I T A_{1 i t} \quad=$ International Tourist Arrival (people)

$\log \beta_{2} I T E_{2 i t} \quad=$ International Tourist Expenditure (IDR)

$\log \beta_{3} L S_{3 i t} \quad=$ International Tourist Length of Stay (days)

$\log _{4}$ Exind $_{4 i t}=$ Exchange rate of Indonesia (US\$)

$\beta_{5} F V_{5 i t} \quad$ Dummy countries of visa-free entry ( $1=$ visa-free, $0=$ otherwise $)$

$\varepsilon_{i t} \quad=$ Stochastic error terms

$\beta_{0} \quad=$ Constant

To quantify the relative influence and elasticity of tourism on Indonesian economic growth, all data except free visa are converted to logarithmic values. The independent variables were chosen based on previous research. As the main independent variable, the 
number of tourist arrivals is the best indicator to measure tourism activities (Uguz, 2017). In addition to the main independent variable, we consider other tourism variables such as length of stay and expenditure level of foreign tourists. The length of stay of foreign tourists is considered as one important determinant of economic growth in the destination countries (Pompili et al., 2019). More length of stay of foreign visitors would create a lot of benefits to host countries through more spending, and this could generate income for the host countries. An increase in the length of stay of tourists would also have an impact on increasing the earnings of accommodation service providers and would indirectly affect the improvement of the national economy (Fadhila \& Rahmini, 2019). Moreover, tourists' expenditure and economic growth are inextricably linked. Tourism opens up new methods to trade with the rest of the world. It is a multi-sector industry that contributes significantly to socio-economic development. Because employment aids in poverty reduction or increases the poor' s purchasing power, tourist development has a favorable impact on economic growth (Al-Hallaq et al., 2019; Lee \& Chang, 2008).

As control variables, we use the Indonesian exchange rate against USD and visa facilities in the regression equation. Since international tourism is a part of international trade, the weakening Indonesian currency may enhance tourism activities through an increase in tourists' consumption capacities (Schnabl, 2008). In terms of visa-free, residents of a country are more likely to visit a destination country that provides convenience through a free entry policy (Mariyono, 2017). Kuzey et al. (2019) explained that applying for a visa requires a fairly long and complicated process. Thus, it can affect the decision of potential tourists to come to a country. A Visa-free would also increase bilateral trade and foreign investment, which in turn leads to higher economic growth (Czaika \& Neumayer, 2017)

Furthermore, three different strategies were utilized to estimate the panel regression model as described. First, the Pooled Least Squares (PLS) model is employed based on assumption that the intercepts and coefficients are constant over time and across individuals, and statistical noise captures disturbances over time and cross-section. Second, the Fixed Effects Model (FEM), commonly known as the Least-Squares Dummy Variable (LSDV) model, calculates the intercept using dummy variables as coefficients. This model accounts for the individual effect by allowing the intercept to vary for each cross-section. Third, rather than treating the intercepts as fixed constants, the Random Effects Model (REM) interprets them as random variables. The intercepts are assumed to be independent of the error term and also mutually independent. In selecting the best model, we performed a series of tests, namely Chow Test, Lagrange Multiplier Test, and Hausman Test.

According to Burlig et al. (2020), the Chow-test aims to compare and choose a model between Pooled Least Square and Fixed Effect Models. If the Chi-Square probability value is more than $5 \%$, Pooled Least Square (PLS) will be selected as the model. Meanwhile, if the Fixed Effects Model (FEM) is selected, the test will be continued to the Hausman Test. The Hausman test is carried out to compare which model is better between Fixed Effects Model and Random Effects Model. If the $p$-value is more than $5 \%$, then the Random Effect is selected as the model since it will give consistent and efficient estimators. Furthermore, 
in comparing between Random Effects and PLS, a Lagrange Multiplier test is required. If the $p$-value is more than $5 \%$, then the PLS is the better one.

\section{Result and Discussion}

After combining all the variables within 10 years, this paper also tested the validity of the data. This test is carried out to check whether the data can be processed further. Then, the best model among others is selected. Table 2 depicts the details of each variable regarding the mean, standard deviation, minimum and maximum number. In addition, since the free-visa policy is a dummy variable, the details were not included.

Table 2 Descriptive statistic

\begin{tabular}{lcccc}
\hline \multicolumn{1}{c}{ Variables } & Mean & Std. Dev & Min & Max \\
\hline Log GDP & 5,58 & 0,59 & 4,63 & 6,35 \\
Log Tourist Arrivals & 220,894 & 346,019 & 5,330 & $1,594,102$ \\
Log Tourist Expenditures & 563 & 655,88 & 24,44 & 2,151 \\
Log Length of Stay & 10 & 3,64 & 4 & 20 \\
Visa Policy (dummy) & - & - & 0 & 1 \\
Log Exchange Rate & 10,423 & 1613,41 & 8,770 & 13,389 \\
\hline
\end{tabular}

Table 3 presents the estimation results from PLS, fixed effects, and random effects. The results obtained from the three procedures were quite similar, while the fixed effects model was selected among the three after a series of tests (Chow Test, LM Test, and Hausman Test).

Table 3 Panel Data Estimations

\begin{tabular}{|c|c|c|c|}
\hline Variables & PLS & FE & RE \\
\hline \multirow[t]{2}{*}{ Log Tourist Arrivals } & 0.006 & $0.364^{* * *}$ & 0.006 \\
\hline & $(0.005)$ & $(0.046)$ & $(0.006)$ \\
\hline \multirow[t]{2}{*}{ Log Tourist Expenditures } & -0.005 & -0.002 & -0.005 \\
\hline & $(0.005)$ & $(0.004)$ & $(0.005)$ \\
\hline \multirow[t]{2}{*}{ Log Length of Stay } & -0.013 & -0.001 & $-0.013^{*}$ \\
\hline & $(0.008)$ & $(0.008)$ & $(0.006)$ \\
\hline \multirow[t]{2}{*}{ Log Exchange Rate of Indonesia } & $-0.072 * * *$ & $-0.035 * * *$ & $-0.072 * * *$ \\
\hline & $(0.013)$ & $(0.005)$ & $(0.001)$ \\
\hline \multirow[t]{2}{*}{ Visa Policy } & $0.132 * * *$ & $0.112 * * *$ & $0.132 * * *$ \\
\hline & $(0.019)$ & $(0.022)$ & $(0.025)$ \\
\hline \multirow[t]{2}{*}{ Constant } & 27.500 & $23.375 * * *$ & $27.500 * * *$ \\
\hline & $(0.081)$ & $(0.022)$ & $(0.076)$ \\
\hline R-Square & 0.230 & 0.039 & 0.230 \\
\hline Observations & 352 & 352 & 352 \\
\hline Chow Test & & 0.000 & \\
\hline Hausman Test $\left(\right.$ Chi $\left.^{2}\right)$ & & $181.39 * * *$ & \\
\hline Lagrange Multiplier (Prob-Chibar²) & & $1.000 * * *$ & \\
\hline
\end{tabular}


As a main independent variable, it seems that foreign tourist arrival has a positive and significant association with economic growth. Specifically, a 1 percent increase in the foreign tourist arrivals is expected to increase GDP growth by 0.36 percentage points as seen in the fixed-effect model. This result is in line with a previous study in Turkey (Akan et al., 2007) which reveals that tourist arrivals are indirectly significant to the economic growth of the destination country through tourist consumption, and increased labor absorption.

On the other hand, tourists' spending and length of stay appear to not have any significant association. This might be due to the unusual behavior of foreign tourists in Indonesia. They only come in huge numbers but do not spend more or stay longer. In particular, the average length of stay of foreign tourists in Indonesia is only 8 days with quite widespread standard deviations. The countries with the longest duration of stay are Russia and Pakistan with a length of stay of 19 days, while the country that contributes as the second largest number of foreign tourists in Indonesia is the country with the shortest duration of stay, only 3 days, which is Singapore. As a result, it has no significant effect on economic growth. This behavior can be attributed to the lack of complementary attractions in a place according to García-Sánchez et al. (2013).

Moreover, García-Sánchez et al. (2013) suggest that tourism activities play a significant role in increasing tourists' daily spending. The majority of tourists' daily costs are spent on golf, gambling, athletic events, and gourmet activities, while visiting amusement parks, water sports, and cultural trips had a smaller influence despite rising daily spending. These findings are extremely important to tourism destination administrators. So far, Indonesia only relies on natural beauty rather than creating new tourist attractions such as amusement parks, international events, shopping centers, and many other attractions as complementary attractions in the main destination. Nevertheless, tourism activities that rely on nature cannot optimize the income generation of tourists (Ollivaud \& Haxton, 2019).

Furthermore, the Indonesian exchange rate variable appears to be in line as hypothesized. An increase (appreciation) of the IDR currency by 1 percent against USD leads to lower economic growth by 0.035 percentage points. Generally, tourists will consider the exchange rate when choosing their destination country (Samirkaş \& Samirkaş, 2016). Countries that have a relatively weaker currency tend to attract more tourists since it is relatively cheaper to visit the countries and make the purchasing power of tourists stronger. Exchange rate volatility is critical for tourism sector development since it has a direct impact on foreign tourist arrivals (Jena \& Dash, 2020). Exchange rate fluctuation makes visitor arrivals less enticing because it influences tourists' decisions to travel to the destination country (Jena \& Dash, 2020). This is held not only for individual passengers who change their vacation plans but also for tour operators who view currency volatility as a risk factor in their business (Jena \& Dash, 2020). As a result, they may send travelers to other destinations where the exchange rate is more stable (Jena \& Dash, 2020). In terms of micro aspect, exchange rate will affect more income for communities and travel service providers, for example, in terms of the enhancement of tourists' purchasing power; hence, the economic growth will be higher (Adha et al., 2018). Therefore, the 
appreciation of currency in the destination country may lower the economic growth through a decrease in tourist arrivals and their consumption of goods and services.

Finally, a visa-free policy seems to have a positive and significant effect on economic growth. Countries that have a visa-free entry tend to have tourists entering Indonesia by 11.2\% higher than those that do not. This is similar to the case in the United States where the largest increase in tourist arrivals comes from travelers with visa-free programs (Neiman \& Swagel, 2009). In the case of Hong Kong, during the outbreak of acute respiratory syndrome (SARS), the Hong Kong government launched a free-visa policy for foreigners, which increased foreign tourist arrivals, especially from Mainland China, Taiwan, and Japan (Cheng, 2012). Therefore, it can be concluded that visa exemption has a positive impact on business trips and vacations which in turn increases the economic growth in the destination country (Li \& Song, 2013).

For robustness check, we use a dynamic panel data model to examine whether foreign tourist activities influence economic growth in different specifications. We account for the lagged variable of GDP as our control variable. Table 3 presents the results. It appears that tourist arrivals are no longer explaining economic growth. The inclusion of lagged variable of GDP has made tourist arrivals lose their significance. It seems that the economic growth is better explained by the growth in the previous period rather than foreign tourism activities.

Table 3 Robustness Check

\begin{tabular}{lccc}
\hline \multicolumn{1}{c}{ Variables } & PLS & FE & RE \\
\hline Log Tourist Arrivals & 0.000 & 0.000 & 0.000 \\
& $(0.000)$ & $(0.000)$ & $(0.000)$ \\
Log GDP ${ }_{\text {- } 1}$ & $0.986^{* * *}$ & $0.988^{* * *}$ & $0.986^{* * *}$ \\
& $(0.001)$ & $(0.001)$ & $(0.000)$ \\
Log Tourist Expenditures & $-0.000^{* *}$ & $-0.000^{* *}$ & $-0.000^{* *}$ \\
& $(0.000)$ & $(0.000)$ & $(0.000)$ \\
Log Length of Stay & -0.196 & -0.000 & -1.96 \\
& $(0.000)$ & $(0.000)$ & $(0.000)$ \\
Log Exchange Rate of Indonesia & $0.005^{* * *}$ & $0.005^{* * *}$ & $0.001^{* * *}$ \\
& $(0.000)$ & $(0.000)$ & $(0.000)$ \\
Visa Policy & $-0.001^{* * *}$ & $-0.003^{* * *}$ & $-0.001^{* * *}$ \\
& $(0.000)$ & $(0.000)$ & $(0.000)$ \\
Constant & $0.360^{* * *}$ & $0.360^{* * *}$ & $0.421^{* * *}$ \\
& $(0.035)$ & $(0.035)$ & $(0.020)$ \\
R-Square & 0.996 & 0.999 & 0.999 \\
Observations & 320 & 320 & 320 \\
Chow Test & & 0.000 & \\
Hausman Test (Chi ${ }^{2}$ ) & & $23.24 * * *$ & \\
Lagrange Multiplier (Prob-Chibar ${ }^{2}$ ) & & $1.000^{* * *}$ & \\
\hline$* * * * * * *$ \\
\hline
\end{tabular}

$* * *, * *, *$ denotes significance at $1 \%$ level, $5 \%$ level, $10 \%$ level, respectively 


\section{Conclusion}

As one of Indonesia's main sources of income, the government has taken several strategies to increase tourism sector revenues. However, it seems that the government only focuses on increasing the number of foreign tourists, while there are no empirical studies that emphasize its link with economic growth in the context of Indonesia. Thus, the motivation of this research is to analyze the association between foreign tourism activities and economic growth. We conducted a series of regression models using panel data from 2006-2016 that links tourism-related variables and economic growth in the context of Indonesia. After running a series of tests, the fixed effects models are selected and show a positive and statistically significant relationship between foreign tourist arrivals and economic growth in Indonesia. However, tourists' spending and length of stay appear to have no statistical effect on Indonesia's economic growth.

These results may imply that the government should not only attract more tourists to come but also design policies to encourage foreign tourists to spend more money and stay longer such as by building complementary attractions and facilities in addition to the main destination. In addition, the Indonesian government should target the country of tourists' origin with higher income to enhance tourists' spending in Indonesia. Furthermore, this research can be extended to reveal factors that determine the length of stay and expenditure of foreign tourists in Indonesia.

\section{References}

Adha, M., Nahar, F., \& Azizurrohman, M. (2018). The impact of trade liberalization on poverty reduction in Indonesia. Jurnal Ekonomi \& Studi Pembangunan, 19(2), 178-185. https://doi.org/10.18196/jesp.19.2.5009

Akan, Y., Işık, C., \& Arslan, I. (2007). The impact of tourism on economic growth: the case of Turkey. Journal of Tourism, 9, 1-24.

Akin Aksu, A., \& Aktaş, A. (2005). Job satisfaction of managers in tourism. Managerial Auditing Journal, 20(5), 479-488. https://doi.org/10.1108/02686900510598830

Al-Hallaq, S. S., Athamneh, A. B., \& Suleiman, H. M. (2019). The impact of foreign direct investment on the growth of the tourism sector in Jordan (1980-2016). Journal of Public Affairs, 20(2). https://doi.org/10.1002/pa.2005

Burlig, F., Preonas, L., \& Woerman, M. (2020). Panel data and experimental design. Journal of Development Economics, 144, 102458. https://doi.org/10.1016/i.jdeveco.2020.102458

Cheng, K. M. (2012). Tourism demand in Hong Kong: income, prices, and visa restrictions. Current Issues in Tourism, 15(3), 167-181. https://doi.org/10.1080/13683500.2011.569011

Chiu, Y.-B., \& Yeh, L.-T. (2016). The threshold effects of the tourism-led growth hypothesis: evidence from a cross-sectional model. Joumal of Travel Research, 56(5), 625-637. https://doi.org/10.1177/0047287516650938

Czaika, M., \& Neumayer, E. (2017). Visa restrictions and economic globalisation. Applied Geography, 84, 75-82. https://doi.org/10.1016/j.apgeog.2017.04.011

Fadhila, R. S., \& Rahmini, N. (2019). Pengaruh jumlah kunjungan wisatawan, tingkat hunian hotel, lama menginap wisatawan terhadap pertumbuhan ekonomi provinsi Kalimantan 
Selatan. JIEP: Jurnal Ilmu Ekonomi dan Pembangunan, 2(1), 21-32. Retrieved from https://ppip.ulm.ac.id/journals/index.php/iiep/article/view/1152

Fayissa, B., Nsiah, C., \& Tadasse, B. (2008). Impact of tourism on economic growth and development in Africa. Tourism Economics, 14(4), 807-818. https://doi.org/10.5367/000000008786440229

Figini, P., \& Vici, L. (2010). Tourism and growth in a cross section of countries. Tourism Economics, 16(4), 789-805. https://doi.org/10.5367/te.2010.0009

Figini, P., Sahli, M., \& Vici, L. (2018). Advances in tourism economics: The sixth IATE (International Association for Tourism Economics) Conference. Tourism Economics, 24(8), 911-914. https://doi.org/10.1177/1354816618811426

García-Sánchez, A., Fernández-Rubio, E., \& Collado, M. D. (2013). Daily expenses of foreign tourists, length of stay and activities: evidence from Spain. Tourism Economics, 19(3), 613-630. https://doi.org/10.5367/te.2013.0218

Gaspar, J. M. (2020). Paul Krugman: contributions to geography and trade. Letters in Spatial and Resource Sciences, 13(1), 99-115. https://doi.org/10.1007/s12076-020-00247-0

Jena, S. K., \& Dash, A. K. (2020). Does exchange rate volatility affect tourist arrival in India: a quantile regression approach. Regional and Sectoral Economic Studies, 20(2), 65-84. Retrieved from https://www.usc.es/economet/reviews/eers2025.pdf

Kuzey, C., Karaman, A. S., \& Akman, E. (2019). Elucidating the impact of visa regimes: A decision tree analysis. Tourism Management Perspectives, 29, 148-156. https://doi.org/10.1016/j.tmp.2018.11.008

Lee, C.-C., \& Chang, C.-P. (2008). Tourism development and economic growth: A closer look at panels. Tourism Management, 29(1), 180-192. https://doi.org/10.1016/i.tourman.2007.02.013

Li, S., \& Song, H. (2013). Economic impacts of visa restrictions on tourism: a case of two events in China. Annals of Tourism Research, 43, 251-271. https://doi.org/10.1016/j.annals.2013.07.007

Mariyono, J. (2017). Determinants of demand for foreign tourism in Indonesia. Jurnal Ekonomi Pembangunan: Kajian Masalab Ekonomi dan Pembangunan, 18(1), 82-92. https://doi.org/10.23917/jep.v18i1.2042

Neiman, B., \& Swagel, P. (2009). The impact of post-9/11 visa policies on travel to the United States. Journal of International Economics, 78(1), 86-99. https://doi.org/10.1016/i.jinteco.2009.01.014

Oh, C.-O. (2005). The contribution of tourism development to economic growth in the Korean economy. Tourism Management, 26(1), 39-44. https://doi.org/10.1016/i.tourman.2003.09.014

Ollivaud, P., \& Haxton, P. (2019). Making the most of tourism in Indonesia to promote sustainable regional development. OECD Economics Department Working Papers, No. 1535. OECD Publishing, Paris. https://doi.org/10.1787/c73325d9-en

Pompili, T., Pisati, M., \& Lorenzini, E. (2019). Determinants of international tourist choices in Italian provinces: A joint demand-supply approach with spatial effects. Papers in Regional Science, 98(6), 2251-2273. https://doi.org/10.1111/pirs.12467

Sakyi, D., \& Egyir, J. (2017). Effects of trade and FDI on economic growth in Africa: an empirical investigation. Transnational Corporations Review, 9(2), 66-87. https://doi.org/10.1080/19186444.2017.1326717

Samimi, A. J., Sadeghi, S., \& Sadeghi, S. (2013). The relationship between foreign direct investment and tourism development: Evidence from developing countries. Institutions and Economies, 5(2), 59-68.

Samirkaş, M., \& Samirkaş, M. C. (2016). The impact of exchange rate on tourism industry. International Business, 1165-1176. https://doi.org/10.4018/978-1-4666-9814-7.ch054 
Savaş B, Beşkaya A, Şamiloğlu F (2010) Analyzing the impact of international tourism on economic growth in Turkey. International Journal of Management, Economics and Business, 6(12), 121-136. Retrieved from https://dergipark.org.tr/en/pub/ijmeb/issue/54588/744121

Schnabl, G. (2008). Exchange rate volatility and growth in small open economies at the EMU periphery. Economic Systems, 32(1), 70-91. https://doi.org/10.1016/i.ecosys.2007.06.006

Schneider, S. S. (1993). Advantages and disadvantages of tourism to an agricultural community. Economic Development Review, 11(4), 76-78.

Sinclair, M. T. (1998). Tourism and economic development: A survey. Journal of Development Studies, 34(5), 1-51. https://doi.org/10.1080/00220389808422535

Soukiazis, E., \& Proença, S. (2007). Tourism as an alternative source of regional growth in Portugal: a panel data analysis at NUTS II and III levels. Portuguese Economic Journal, 7(1), 43-61. https://doi.org/10.1007/s10258-007-0022-0

Statistics Indonesia. (2018). Proportion of tourism contribution to GDP (percent), 20152017. Retrieved from https://www.bps.go.id/indicator/16/1188/1/proporsikontribusi-pariwisata-terhadap-pdb.html

Statistics Indonesia. (2020). Total foreign exchange of tourism sector (billion us \$), 20162018. Retrieved from https://www.bps.go.id/indicator/16/1160/1/total-foreignexchange-of-tourism-sector.html

Sulasmiyati, S. (2019). Analyzing inflation influence toward the number of foreign tourists visiting Indonesia and their impact on Indonesia's economic growth. Media Bina Ilmiah, 14(3), 2181. https://doi.org/10.33758/mbi.v14i3.321

Uguz, S. C. (2017). Role of tourism on foreign exchange of developing countries and case of Turkey. Pressacademia, 4(1), 59-66. https://doi.org/10.17261/pressacademia.2017.379 